Tuangsit Wataganara*, Pornpimol Ruangvutilert, Prasert Sunsaneevithayakul, Anuwat Sutantawibul, Monsak Chuchotirot, Buraya Phattanachindakun and Kusol Russameecharoen

\title{
Minimizing cross transmission of SARS-CoV-2 in obstetric ultrasound during COVID-19 pandemic
}

https://doi.org/10.1515/jpm-2020-0228

Received May 26, 2020; accepted June 28, 2020; published online July 20,2020

\begin{abstract}
Severe acute respiratory syndrome coronavirus2 (SARS-CoV-2)-associated infection (COVID-19) is affecting populations worldwide. This statement may serve as guidance for infection prevention and safe ultrasound practices during the COVID-19 pandemic. Ultrasound examination is a fundamental part of obstetric care, yet it is a potential vector for transmission of SARS-CoV-2. Decontamination methods should always be implemented for ultrasound equipment, especially in the presence of suspected or confirmed COVID-19 cases. There must be workflow policies to protect pregnant women and healthcare providers from nosocomial cross transmission of SARS-CoV-2. Cleaning and disinfecting of equipment must be in accordance with their potential of pathogen transmission. Consider using telemedicine and genetic technologies as an adjunctive of obstetric ultrasound to reduce patient crowding. Patient triage and education of healthcare providers of infection prevention are crucial to minimize cross contamination of SARS-CoV-2 during obstetric ultrasound.
\end{abstract}

Keywords: acute respiratory distress syndrome; ARDS; coronavirus disease 2019; coronavirus; maternal morbidity; MERS; pandemic; SARS; severe acute respiratory syndrome; virus.

\footnotetext{
*Corresponding author: Tuangsit Wataganara, MD, Division of Maternal-Fetal Medicine, Department of Obstetrics and Gynecology, Faculty of Medicine Siriraj Hospital, 2 Prannok Road, Bangkoknoi, Bangkok, 10800, Thailand, Phone: 011662419 7000, Fax: 011662418 2662, E-mail: twataganara@yahoo.com Pornpimol Ruangvutilert, Prasert Sunsaneevithayakul, Anuwat Sutantawibul, Monsak Chuchotirot, Buraya Phattanachindakun and Kusol Russameecharoen: Division of Maternal Fetal Medicine, Department of Obstetrics and Gynecology, Faculty of Medicine Siriraj Hospital, Bangkok, Thailand
}

\section{Introduction}

Severe acute respiratory syndrome coronavirus-2 (SARS-CoV-2)-associated infection (coronavirus disease 2019 or COVID-19) is affecting populations worldwide. The virus is airborne and contagious. More severe outcomes are possible in pregnant women[1]. Ultrasound examination is a fundamental part of basic and advanced care in obstetrics [2]. Obstetric ultrasound unit is a potential vector for transmission of SARS-CoV-2 for several reasons. Ultrasound examination is subjected to close and prolonged personal contact. The examination suites tend to be small and restricted for natural ventilation. The central air conditioning is generally closed vented, and without High Efficiency Particulate Air (HEPA) filtration to arrest very fine particle. There are repeated handling of transducers, machine console, keyboards, touch screens, trackballs, and recording devices [3, 4]. Basic knowledge of infection prevention measures is usually lacking among ultrasound providers [5].

Guidelines for prevention of SARS-CoV-2 infection from transabdominal, transvaginal, and transrectal ultrasounds are readily available [6-8]. Guidance documents for management of COVID-19 in pregnant women have been published by authors from areas most affected by the virus thus far, such as China, Singapore, Hong Kong, and Italy [9-13]. These recommendations are based on limited, and rapidlyevolving, body of evidence. Although most elective obstetric ultrasound has been curtailed by administrative or governmental decree, there are emergency conditions and timesensitive interventions which ultrasound in pregnant women is needed. This article may serve as a guidance to minimize cross transmission of SARS-CoV-2 among patients and healthcare providers (HCPs) when performing ultrasound examinations on pregnant women during global pandemic. The term HCPs used in this article is inclusive for sonologists, sonographers, nursing staffs, and all other staffs who provide obstetric ultrasound service. Local experiences in Thailand, where COVID-19 has been reasonably well controlled, are used as examples throughout this manuscript. This guidance is current at time of publication and further updates may be provided as new evidence emerges. 


\section{Pandemic of COVID-19 and maternal-fetal health}

Originated from animal, now SARS-CoV-2 is currently involved in human to human transmission at global pandemic scale $[14,15]$. The SARS-CoV-2 is a relatively small ribonucleic acid (RNA) virus transmitted through respiratory droplets $[16,17]$. The SARS-CoV-2 laden particles can remain suspended in the air for hours and on a static surface for a few days [18]. The SARS-CoV-2 mainly spreads when virus-laden droplets from a person's mouth or nose are transferred to mouth, nose, or eyes of other people. Other coronaviral infections such as the SARS-CoV1 and Middle East respiratory syndrome (MERS) increased risks for preterm deliveries, stillbirths, pulmonary complications, and deaths in pregnant women [11, 19]. Recent evidence suggests SARS-CoV-2 may also cause more serious complications in pregnant women [11, 20-22]. Lifethreatening complications during pregnancy from COVID19 may be less than those observed from influenza A (H1N1). Basal atelectasis from gravid uterus, reduce functional residual capacity (lower lung reserves), and 30\% increase oxygen consumption predispose pregnant women with COVID-19 to develop coronaviral pneumonias which could rapidly deteriorate to respiratory failure [23]. T-helper 2 (Th2) system is dominant during pregnancy to protect the fetus. This leaves pregnant woman more vulnerable to viral infections, which are more effectively contained by the T-helper 1 (Th1) system [24]. Although there was a report of placental injuries from COVID-19, there is no enough evidence to confirm spontaneous vertical transmission of SARS-CoV-2 [25, 26]. Placental changes in COVID-19 are decidual arteriopathy and maternal vascular mal-perfusion, which reflect a systemic inflammatory or hypercoagulable state influencing intervillous oxygenation and may increase occurrence of preeclampsia [27]. However, the actual consequences of COVID-19 to maternal and fetal health remained controversial at the time of writing this manuscript $[28,29]$.

\section{Detection and confirmation of COVID-19}

Approximately $80 \%$ of SARS-CoV-2 infections are asymptomatic [30]. For those who are symptomatic, it takes an average of 6 days, to up to 14 days, after infection with SARS-CoV-2 for symptoms to show. Clinical presentations of COVID-19 can be varied. Most patients develop mild to moderate flu-like symptoms, i.e., fever, dry cough, and tiredness, which overlap with symptoms of other viral respiratory diseases. Some may experience myalgia, sore throat, diarrhea, conjunctivitis, headache, loss of taste or smell, skin rashes, and discoloration of fingers or toes, which can be self-remission. Serious pulmonary manifestations are uncommon. The SARS-CoV-2 can be found in feces, $[15,31]$ but not in vaginal secretion [32]. Fecal-oral and sexually transmission do not appear to be a major route of transmission of SARS-CoV-2.

During the pandemic of COVID-19, attention must be paid at collecting clinical and epidemiological indicators, i.e., respiratory symptoms, fever, recent travel history to area with serious outbreak, or contact with confirmed cases [33]. Patient under investigation (PUI) is defined as a suspected case on the basis of the followings; [1] pneumonia of unknown origin, or [2] fever $\left(\geq 37.5^{\circ} \mathrm{C}\right)$ and/or respiratory symptoms, or [3] epidemiological correlation with the domestic mass outbreak or contact with a confirmed case of COVID-19 and exhibiting fever and/or respiratory symptoms within 14 days. Infection can be confirmed within 90 min by nasopharyngeal swab for detection of viralspecific RNA with real-time reverse transcription polymerase chain reaction (RT-PCR) [34]. Serologic strip test to detect to detect antibody (IgG and IgM) in the blood serum and plasma takes only $15 \mathrm{~min}$, but the clinical roles of antibody testing remained controversial at the time of writing this manuscript [35]. Further managements of pregnant women who are tested positive for SARS-CoV-2 are not within the scope of this article.

\section{Cross transmission of SARS-CoV-2 during obstetric ultrasound}

Although most of the reported COVID-19 outbreaks are in a household or a workplace rather than in a health care facility; ultrasound providers are particularly at higher risk of contracting SARS-CoV-2. Preventing HCPs from getting SARS-CoV-2 is particularly important because HCPs are able to transfer the virus to many vulnerable patients before they become symptomatic. Special attention should be paid at HCPs who are at higher risk for severe complications if they get COVID-19, i.e., those older than 60 years, and those with underlying conditions such as hypertension, diabetes mellitus, cardiovascular disease, chronic respiratory disease, and cancer [36]. Advanced obstetric ultrasounds and prenatal interventional procedures increase the exposure time of HCPs to the patients $[2,37,38]$. 
It is important to note that the viability of SARS-CoV2-laden droplets on surfaces depends on the type of surface and temperature [39]. The virus may survive on dry inanimate surfaces from two to nine days $[8,39]$. Training, practicing, and auditing basic infection prevention and control within the obstetric ultrasound unit are important [40]. Recent survey indicated that upto $60 \%$ of ultrasound providers do not receive adequate training for sanitization of the equipment. In addition, 33\% do not have an access to written infection control policies [4]. As the SARS-CoV-2 status of pregnant women is not often disclosed prior to an obstetric scan; infection control protocols during the global outbreak may include appropriate use of personal protective equipment (PPE) (Table 1). Cleaning and disinfection of ultrasound equipment can mitigate the risk of potential infection [41]. Training materials for infection control should be easy to understand and available in the appropriate language and literacy level for all HCPs. The steps of 'cleaning', 'low-level disinfection' (LLD), 'highlevel disinfection' (HLD), and sterilization are described in Table 2.

\section{Considerations for healthcare providers to prevent cross \\ transmission of SARS-CoV-2 during obstetric ultrasound}

Since most of the SARS-CoV-2 infections are asymptomatic; standard precautions should be undertaken as part of every examination. They include [1] hand hygiene before and after each examination, [2] appropriate use of PPE, [3] maintenance of clean equipment and working

Table 1: Personal protective equipment (PPE) relevant to providers of obstetric ultrasound in the context of coronavirus disease 2019 (COVID-19) [41, 69, 72].

\begin{tabular}{ll}
\hline PPE & Remarks \\
\hline Face mask & $\begin{array}{c}\text { Surgical face mask is adequate } \\
\text { in most circumstances } \\
\text { N95 and FFP3 (higher level of protection) } \\
\text { in possible presence of infected aerosol, } \\
\text { i.e., point-of-care ultrasound during } \\
\text { labor and delivery }\end{array}$ \\
$\begin{array}{l}\text { Eye protection } \\
\begin{array}{l}\text { Gloves } \\
\text { Gowns, hair, and } \\
\text { shoe covers (fluid } \\
\text { impermeable) }\end{array}\end{array}$ & $\begin{array}{l}\text { Preferably latex-free. } \\
\text { This is to minimize the transfer of } \\
\text { pathogens to the clothing and shoes. }\end{array}$ \\
\hline
\end{tabular}

environment, and [4] correct disposal of waste. Washing with warm water and soap $>20 \mathrm{~s}$ remains the gold standard for hand hygiene, especially if hands are visibly soiled, because it removes oils from the skin that can harbor microbes. Soap can kill SARS-CoV-2 and most viruses by attacking at the lipid bilayer capsid of the viral nanoparticles [42]. Soap to be used for frequent hand washing should not contain any harsh ingredients or fragrance that may be irritating to the skin. Alternatively, the use of hand sanitizers in between touching the patients is a good substitute in a busy practice. Hand sanitizers are either alcohol-based or alcohol-free. Alcohol-based products contain between 60 and 95\% of isopropyl alcohol, ethyl alcohol (ethanol), or n-propyl alcohol (n-propanol). This concentration of alcohol can destroy envelop protein and kill most viruses including coronaviruses. Incorrect use of hand sanitizer, i.e., inadequate volume or wiping off before it dries, is common and is jeopardizing its germicidal effects [43]. Alcohol is highly flammable and irritant to some. Alcohol-free products contain quaternary ammonium compounds (usually benzalkonium chloride), which have a weaker antimicrobial efficacy than alcohol, but still is effective against coronaviruses [44]. Hand hygiene should also be performed when donning and doffing of gloves and other PPE.

Scanning should be performed with one clean hand holding a transducer, while the other hand is semi-clean to operate the machine's dashboard and to handle the coupling gel bottle. Gloves may be used with the scanning hand and changed after each examination. The PPE may be used as appropriate and as per the institutional protocols, as shown in Figure 1. Shorter working hours and work in rotation can minimize the number of essential HCPs present in each location. Older ( $>60$ years old) HCPs or those with underlying medical conditions should not be allocated to work with PUI or confirmed COVID-19 patients, or in areas with high-volume patient contact, i.e., emergency department. Because a number of HCPs have already been off work after exposure to COVID19 cases, small teams should be consolidated and scheduled to work on alternating weeks to lessen the exposure. It is important to understand levels of anxiety and depression in HCPs working in obstetric ultrasound at this time.

\section{Prioritizing the indications of obstetric ultrasound}

During COVID-19 pandemic, the prior anxiety associated with diagnosis of serious obstetric or fetal conditions can 


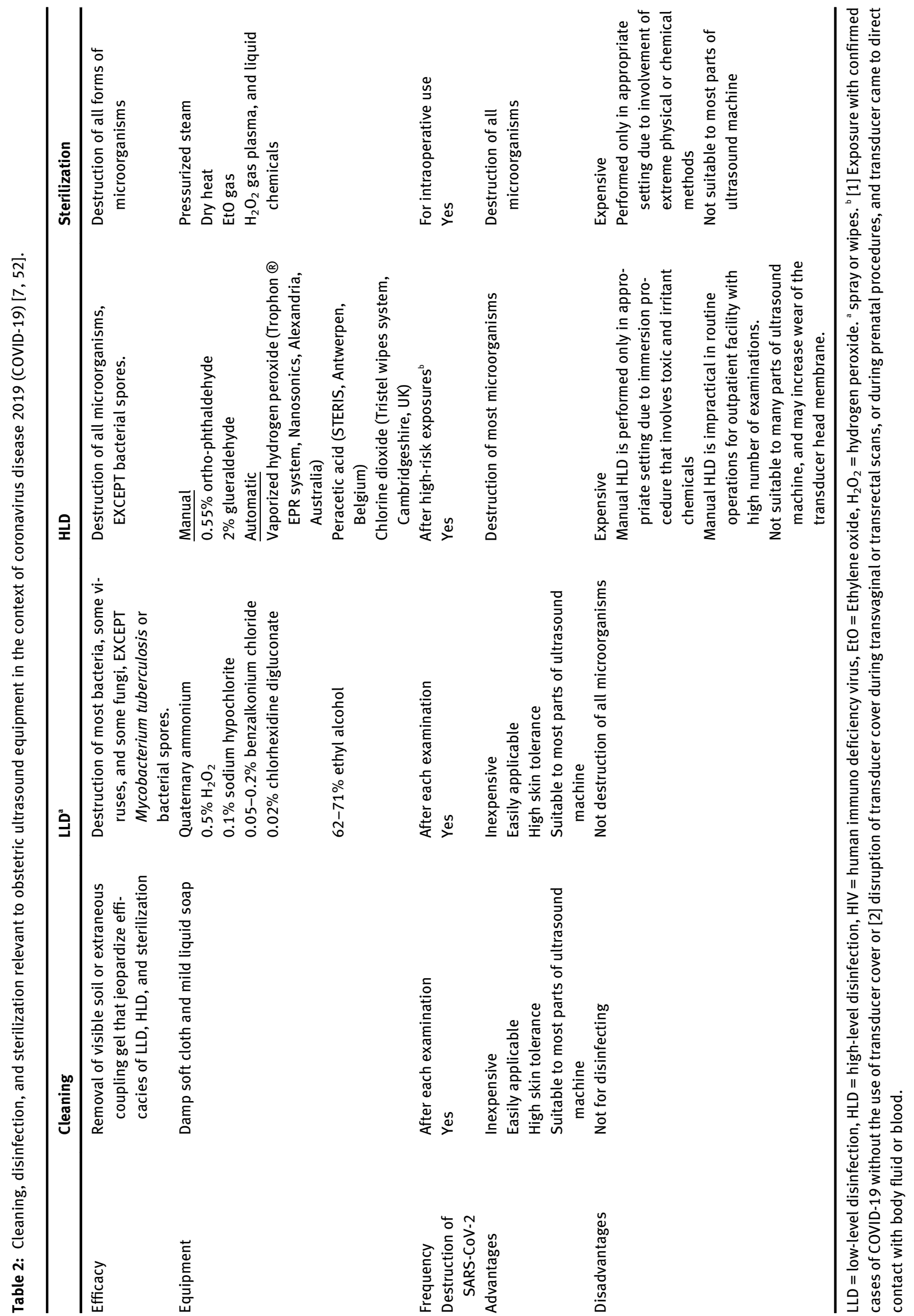




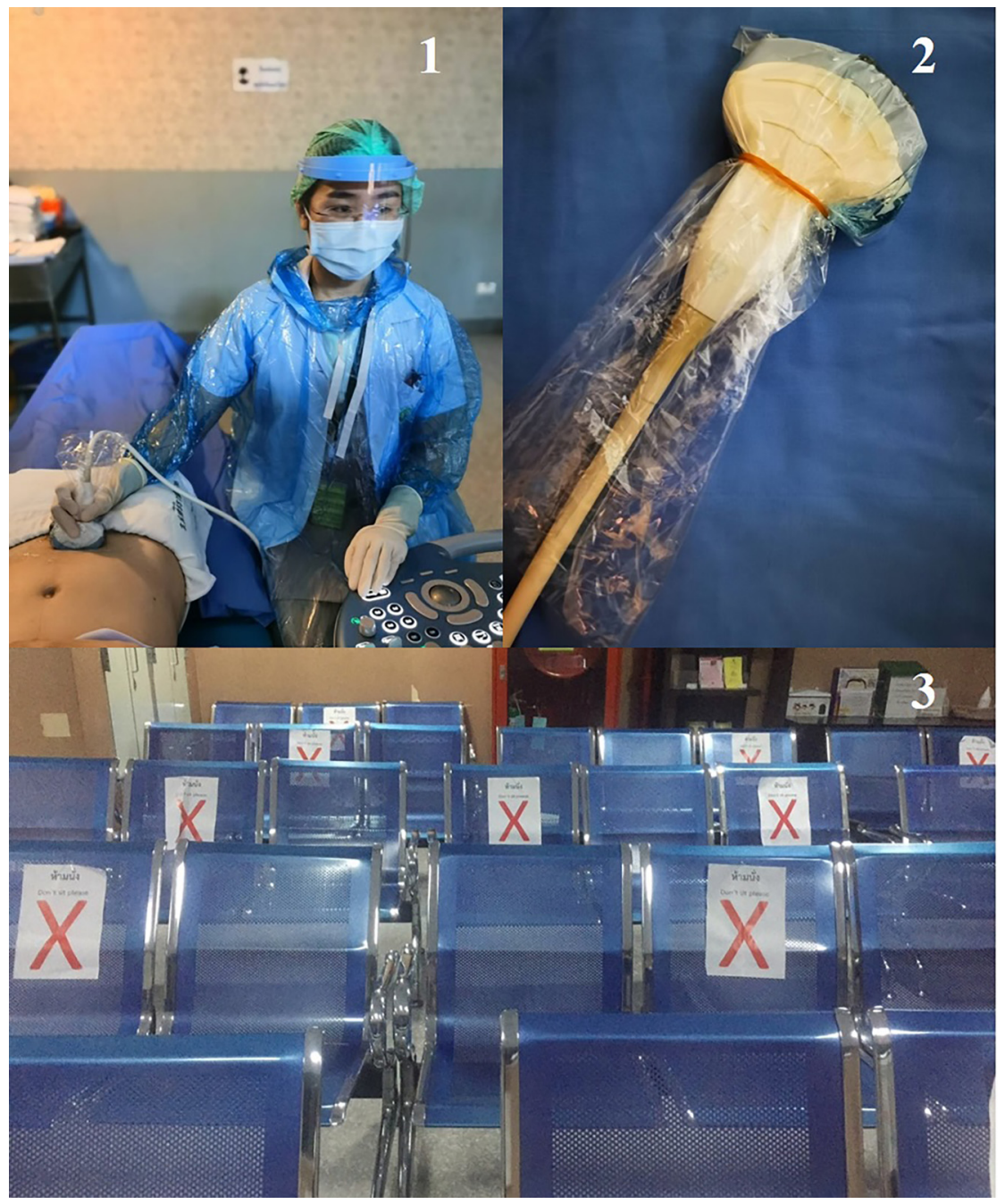

Figure 1: Arrangement of obstetric ultrasound services during COVID-19 pandemic.

(1) Ultrasound provider wears makeshift cover-all gown from disposable raincoat (water-proof), with mask and face shield. Also note that non-essential items in the examination suite have been removed,

(2) Makeshift transducer cover from storebought plastic bag and rubber band.

(3) Enforcement of alternate seating in waiting area to ensure distance keeping $\geq 1 \mathrm{~m}$ apart (Source; Tuangsit Wataganara, Division of Maternal Fetal Medicine, Department of Obstetrics and Gynecology, Faculty of Medicine Siriraj Hospital). be heightened by the concern of contracting SARS-CoV-2. To minimize the chance of having an asymptomatic carriers attending the obstetric ultrasound unit, triage is best undertaken before the patient arrival. Patients should be contacted by phone before the appointment date to check for symptoms. Those who are symptomatic, considered a PUI, or have been diagnosed with COVID-19 within 14 days should be instructed to postpone their non-urgent ultrasound examination [12]. Before entering the waiting area, everyone must be checked with thermo screening and questioning with standardized checklists as per recommendations of local or institutional authorities (i.e., www. thaicovids.com) at $\geq 1 \mathrm{~m}$ away.[45] Thermo screening is not always truthful since some women took antipyretics medication before the screening.

It is important to [1] triage of patients to routine or emergent examination [2] delay or cancel non-essential examinations (Table 3), to minimize patient crowding, [3] space the waiting room seats to $\geq 1 \mathrm{~m}$ apart, [4] limit the number of entourages in waiting area to $\leq 1$, and none in the examination suite, [5] prohibit school-age children from entering the waiting area because they are more likely to be asymptomatic carriers of SARS-CoV-2, [6] encourage the use of telemedicine and genetic technologies, such as noninvasive prenatal testing (NIPT) as an adjunctive or replacement of first trimester scan, [46] and [7] prohibit or reduce trainees on site.

Digital technologies have been put to use during the COVID-19 pandemic. For example, the Ministry of Digital Economy and Society (Thailand) recently released a smartphone application "Thai Chana" (Thailand Wins, downloadable from www.thaichana.com) to facilitate safety for both clients and establishments during the COVID-19 era [47]. Another smartphone application "Skan \& Go" is also available for patients of Faculty of Medicine Siriraj Hospital (Thailand) (downloadable from https:// www.si.mahidol.ac.th/th/news_covid19.asp) [48]. The use of $\mathrm{QR}$ codes generated from these smartphone applications 
Table 3: Schedule management for obstetric ultrasound during coronavirus disease 2019 (COVID-19) pandemic according to the essentialness $[13,53,73,74]$.

\begin{tabular}{|c|c|c|}
\hline Indications & Scheduling management & Remarks \\
\hline Bleeding in early pregnancy & $\begin{array}{l}\text { Point-of-care ultrasound to determine fetal } \\
\text { life and location of pregnancy }\end{array}$ & $\begin{array}{l}\text { Consider re-scheduling for ultrasound according to } \\
\text { the clinical suspicion. }\end{array}$ \\
\hline $\begin{array}{l}\text { Dating (re-assurance) scan at } \\
\text { 6-10 weeks' }\end{array}$ & Cancel & $\begin{array}{l}\text { Consider re-scheduling for first trimester scan at } \\
11-13+6 \text { weeks' }\end{array}$ \\
\hline $\begin{array}{l}\text { First trimester screening at } \\
\qquad 11-13+6 \text { weeks' }\end{array}$ & $\begin{array}{l}\text { Postpone for } 1-2 \text { weeks, but not after } \\
13+6 \text { weeks' }\end{array}$ & $\begin{array}{l}\text { Consider informing the low-risk results of combined } \\
\text { first-trimester screening by phone }\end{array}$ \\
\hline \multirow[t]{2}{*}{$\begin{array}{l}\text { Transvaginal scan for cervical length } \\
\text { assessment }\end{array}$} & $\begin{array}{l}\text { Cancel in those clinically low-risk for } \\
\text { spontaneous preterm birth }\end{array}$ & $\begin{array}{l}\text { Consider transabdominal assessment of the cervix at } \\
\text { the time of second trimester scan. Confirmation } \\
\text { with transvaginal assessment in those with cervi- } \\
\text { cal length }<35 \mathrm{~mm} \text { or funneling of the internal os. }\end{array}$ \\
\hline & $\begin{array}{l}\text { Scan without delay in those clinically high- } \\
\text { risk for spontaneous preterm birth } \\
\text { (i.e., history of previous spontaneous } \\
\text { preterm birth, cervical conization) }\end{array}$ & $\begin{array}{l}\text { Short cervix may warrant intervention i.e., cervical } \\
\text { cerclage, progestogen supplement }\end{array}$ \\
\hline Anomaly scan at $18-20$ weeks' & $\begin{array}{l}\text { Postpone for } 1-2 \text { weeks, but not after legal } \\
\text { gestational weeks for termination. }\end{array}$ & $\begin{array}{l}\text { Second trimester scan should be given priority over } \\
\text { first trimester scan }\end{array}$ \\
\hline $\begin{array}{l}\text { Prenatal diagnostic and therapeutic } \\
\text { procedures }\end{array}$ & Scan without delay & $\begin{array}{l}\text { These essential procedures do not generate aerosol } \\
\text { particles. }\end{array}$ \\
\hline $\begin{array}{l}\text { Routine growth scan in the third } \\
\text { trimester in low-risk women }\end{array}$ & Cancel or postpone until 36 weeks' & $\begin{array}{l}\text { Routine third trimester scan is not proven to reduce } \\
\text { perinatal morbidity }\end{array}$ \\
\hline $\begin{array}{l}\text { Fetal well-being, amniotic fluid index, } \\
\text { and Doppler studies from }\end{array}$ & Scan without delay & $\begin{array}{l}\text { The scan is critical for decision making for prenatal } \\
\text { intervention or early delivery. }\end{array}$ \\
\hline $\begin{array}{l}\text { 28-41 weeks' in high-risk } \\
\text { pregnancies }\end{array}$ & & $\begin{array}{l}\text { High-risk pregnancies include, but not restricted to, } \\
\text { fetal growth restriction, red blood cell iso- } \\
\text { immunization, monochorionic twins } \\
\text { Scan interval depends on the severity of the condition }\end{array}$ \\
\hline $\begin{array}{l}\text { Suspected abnormal placentation } \\
\text { i.e., low-lying and placenta previa, } \\
\text { placenta accreta, or vasa previa }\end{array}$ & Scan without delay & $\begin{array}{l}\text { The scan is critical for decision making and early } \\
\text { notification with blood bank, especially in } \\
\text { shortage of blood products supplies during the } \\
\text { pandemic. }\end{array}$ \\
\hline Research recruitment & Cancel & $\begin{array}{l}\text { Consider re-scheduling only for interventional } \\
\text { research that may benefit the patients. }\end{array}$ \\
\hline
\end{tabular}

help managing crowding and facilitate contact tracing in case of cluster outbreaks in the establishment.

\section{Sanitization of ultrasound equipment}

Reusable medical devices such as ultrasound transducers are potential vector in the cross transmission of healthcareassociated infection. Approximately $60 \%$ of transabdominal and $14 \%$ of transvaginal transducers are contaminated with pathogen after use [49]. Reprocessing requires cleaning, followed immediately by disinfection or sterilization depending on the procedure and risk. Sanitization can reduce the number of, but not completely eliminate, viruses present on a surface. Damp cloth and small amount of mild non-abrasive liquid soap are used to clean the remaining coupling gel that barrier and diminish the efficacy of disinfectant agents that will be followed. There are non-critical (low-risk), semi-critical (mediumrisk), and critical (high-risk) levels of disinfection for obstetric ultrasound transducers, as per the Spaulding Classification system (Table 4) [50, 51]. The number of transducers connected to the ultrasound machine should be reduced to a minimum. Non-essential transducers, i.e., linear, three-dimensional, and electronic transducers, should be stored away in a clean closed cabinet and brought out as needed.

Transabdominal transducers can then be disinfected with antimicrobial sprays and wipes (antiseptic-impregnated towel), such as Clorox ${ }^{\circledR}$ Disinfecting Wipes, Clorox ${ }^{\circledR}$ Healthcare Bleach Germicidal Disinfectant Wipes, Super Sani-Cloth Germicidal Disposable Wipes, or Lysol ${ }^{\circledR}$ spray, and allow the surface to air dry $[52,53]$. Be careful when 
Table 4: Categorization of equipment in obstetric ultrasound based on their potential for pathogen transmission [50, 51, 73].

\begin{tabular}{|c|c|c|c|c|}
\hline Category & Definition & Example & $\begin{array}{l}\text { Cleaning strategy after each } \\
\text { use }\end{array}$ & Remarks \\
\hline $\begin{array}{l}\text { Critical } \\
\text { (high-risk) }\end{array}$ & $\begin{array}{l}\text { Intended to penetrate skin } \\
\text { or mucous membranes }\end{array}$ & Needle guidance & $\begin{array}{l}\text { HLD/sterilization (depending } \\
\text { on institutional guidelines) }\end{array}$ & Use sterile transducer cover \\
\hline \multirow[t]{2}{*}{$\begin{array}{l}\text { Semi-critical } \\
\text { (medium-risk) }\end{array}$} & $\begin{array}{l}\text { Come into contact with non- } \\
\text { intact skin, blood, body } \\
\text { fluids, and mucous } \\
\text { membranes }\end{array}$ & $\begin{array}{l}\text { Transvaginal and trans- } \\
\text { rectal transducers }\end{array}$ & $\begin{array}{l}\text { LLD/HLD (depending on the } \\
\text { level of procedure sterility } \\
\text { and known infectious status } \\
\text { of the patients) }\end{array}$ & $\begin{array}{l}\text { Use non-sterile transducer } \\
\text { cover }\end{array}$ \\
\hline & & $\begin{array}{l}\text { Intraoperative } \\
\text { transducer }\end{array}$ & LLD/HLD & Use sterile transducer cover \\
\hline \multirow[t]{2}{*}{$\begin{array}{r}\text { Non-critical } \\
\text { (low-risk) }\end{array}$} & $\begin{array}{l}\text { Come into contact with } \\
\text { clean, intact skin, but not } \\
\text { mucous membranes }\end{array}$ & $\begin{array}{l}\text { Transabdominal } \\
\text { transducer }\end{array}$ & LLD & $\begin{array}{l}\text { Use non-sterile transducer } \\
\text { cover for PUl or confirmed } \\
\text { COVID-19 cases }\end{array}$ \\
\hline & & $\begin{array}{l}\text { Interventional percuta- } \\
\text { neous procedure } \\
\text { transducer }\end{array}$ & LLD & Use sterile transducer cover \\
\hline
\end{tabular}

HLD, high-level disinfection; LLD, low-level disinfection; HIV, human immuno deficiency virus; PUI, patient under investigation.

spraying disinfectant agents on high contact surfaces such as registration counters as splashes can further disperse the virus. Sanitizing wipe may be more appropriate. Do not disinfect ultrasound transducer, cables, USB connectors, or strain reliefs with $\geq 70 \%$ isopropyl alcohol as it can damage those parts and invalidate warranties or service contract. Hand sanitizer should not be used to disinfect ultrasound equipment. Products used for cleaning or disinfection must be checked for compatibility and contact time to ensure effective germicidal as per specified by the manufacturers. Gloves and eye protections are required for cleaning and disinfection. Type $\mathrm{C}$ ultraviolet light may be used to clean all transducer at the end of the day [54].

Transvaginal and transabdominal transducers used for prenatal intervention must be used with protective mechanical barriers to prevent direct contact with body fluid and blood. Transvaginal transducers are persistently tainted with pathogen because the use of latex condoms does not always prevent smear contamination [54]. Ideally, these transducers must undergo HLD after each use [55, 56]. In reality, HLD after each use or when there is disruption of the barriers is difficult due to limited time from a large caseload [5]. Ruptures of transducer cover sometimes are unrecognized, and the transducer comes into direct contact with body fluid and blood [52]. Choosing the optimal method to disinfect these transducers need to consider other pathogens aside from SARS-CoV-2 [7, 32]. Although most commercially available disinfecting wipes (LLD) cannot eliminate all microorganisms; they are still effective against common viral pathogens such as human papillomavirus (HPV), human immunodeficiency virus (HIV), and coronaviruses [57].
Protective mechanical barriers such as medical gloves, transducer cover, or condoms, are generally made with latex (natural rubber). Latex condoms effectively block most viruses, including HPV $(0.05 \mu \mathrm{m})$, HIV $(0.1 \mu \mathrm{m})$, and coronaviruses $(0.11 \mu \mathrm{m})[58,59]$. Transducer covers with pore sizes of less than $0.03 \mu \mathrm{m}$ (i.e., CIV-Flex ${ }^{\mathrm{TM}}$, Civco, Iowa, USA) are now available. The protective mechanical barrier must be carefully removed from the transducer after each scan, and disposed properly. Be careful not to smear contaminate the transducer during the removal. Gloves should be worn to remove the transducer cover and to clean the transducer, then hands should be thoroughly washed with soap and water. If disruption of condoms is found, the transducer should ideally undergo HLD with chemical agents.

In the context of COVID-19, the normal practices of cleaning and disinfection of ultrasound transducers used in obstetrics to denature SARS-CoV-2 are not changed (Table 4). Non-sterile cover can be put on transabdominal transducers to serve as a barrier during the diagnostic scan in patients with suspicious history, but not triaged as PUI (Figure 1). The use of bacteriostatic lubricant for coupling does not significantly reduce the rate of infection [60]. Latex sensitivity can be identified by questioning about itching, rash or wheezing after wearing latex gloves or inflating a toy balloon. Positive histories should be flagged in the patient's chart. Reaction to latex range from contact urticaria to systemic anaphylaxis which requires prompt treatment [61]. "Hypoallergenic" latex gloves do not necessarily prevent allergic reaction; therefore if latex sensitivity is suspected, consider using transducer covers made with alternative materials, such as plastic. 
Contaminated ultrasound gel has been implicated in outbreaks of other nosocomial infections but coronaviruses [62]. Sterile single-use gel packet may be preferred in all invasive prenatal procedures, and for examination of PUI or confirmed COVID-19 cases. Multi-dose containers are more widely used. Empty containers should be discarded, and should not be refilled. The container should be sealed the when not in use. Coupling gel is dispensed from its container with the semi-clean hand. Direct contact between the dispensing tip and other persons or equipment, including the ultrasound transducer, should be avoided. The container should be wiped with LLD agents after each examination.

Ancillaries of ultrasound machine, i.e., track ball, touch screen, etc., are cleaned and disinfected much less frequently than the ultrasound transducer because it is time consuming. The use of plastic covers for the machine's console can be helpful, especially if the machine is to be used for examination of PUI or confirmed COVID-19 cases. If the plastic cover is visibly soiled, it must be cleaned. The use of a plastic cover does not preclude the need for cleaning the equipment at the end of daily service.

\section{Point-of-care obstetric ultrasound during COVID-19 pandemic}

The development of good quality and portable ultrasound machines has led to focused approaches for clinical decision making and for procedural guidance in obstetric patients who would otherwise have very limited or no access to standard imaging [63]. Point-of-care obstetric ultrasound can take place in labor and delivery ward, accident and emergency medicine units, and critical care services. Mobile ultrasound machines are often used for examination of PUI and confirmed COVID-19 patients due to simpler user interface, ease of transport, and easier cleaning. If active screening for SARS-CoV-2 for all in-house obstetric patients is not enforced in the establishment, it is important that all mobile ultrasound equipment must be regularly sanitized. All items should be cleaned and LLD immediately after each use on patient with unknown COVID-19 status. Portable ultrasound machines in labor and delivery unit is more vulnerable to viral contamination because aerosolized droplets are commonly generated during the process of vaginal births.

Although procedures conducted in obstetric ultrasound unit generally involve blood and amniotic fluid; they do not commonly generate aerosolized droplets. Ultrasound transducers for prenatal procedures require LLD or HLD before and after use. Ultrasound transducers for the operating theater may require HLD [8]. Intraoperative cross transmission of SARS-CoV-2 may theoretically be increased with gas laparoscopy and procedures that require endotracheal intubation. Knowing the patient's preoperative SARS-CoV-2 status, either by nasopharyngeal swab or serologic strip test, would avoid or defer certain procedures while the patient is contagious and to protect HCPs appropriately. Some fetal conditions amendable for in utero interventions may alternatively be managed after birth in accordance with the context of local resources [64]. Procedures of unproven benefit should not be offered [65]. Fetal care team must weigh the risks and benefits to the fetus and the mother when the situation gets more complex with a continuous change of evidence and logistic challenges in individual healthcare system [66].

\section{Physical arrangement of obstetric ultrasound unit in the context of COVID-19}

Environment of each obstetric ultrasound unit is different. Ultrasound equipment needs to be kept air conditioned because critical elevation of internal system temperature can cause irreparable damages. Transmission of respiratory viruses like SARS-CoV-2 occurs more easily within closed setting. Clinical service model should be built around the principles of workplace segregation, responsible social distancing, containment of cross infection to HCPs, appropriate use of PPE, and telemedicine [11].

Ideally, a single unit air conditioning should be vent open mode (open to outside air). Physical barriers, i.e., plastic window panels, can be put on in reception areas to protect the patients and HCPs from exchanging aerosolized droplets. There should be hand sanitizing stations installed near the entrance to waiting area and registration counters. Data from a hospital in Wuhan, China during the first outbreak of COVID-19 showed that the most contaminated objects and are self-service printers (20.0\%), hand sanitizer dispensers (20.3\%), and glove boxes (15.4\%) [67]. The risk of SARS-CoV-2 transmission via touching paper document is low [68]. Guest chairs in the waiting area must be spaced $\geq 1 \mathrm{~m}$ apart (Figure 1). Absorbent materials like bed linen, chair fabric covers, and unnecessary curtains should be removed. At the beginning and the end of daily service, wipe computer keyboard and mouse at registration counters, doorknobs, patient beds, guest chairs, sonographer chairs, countertops, cabinet door handles, and light switches with soap and water, 
followed by LLD agents. If paper bed cover is used, it must be removed with gloved hands, folded, and disposed of immediately at the end of each examination.

\section{Workflows for safe obstetric ultrasound services in suspected and confirmed COVID-19 cases}

Medical institutions are activating COVID-19 protocols that are adapted from smaller-scale viral pandemics such as influenza A, SARS, and MERS [69]. There must be practical approaches and policies to provide optimal ultrasound services for confirmed COVID-19 pregnant women, and to prevent nosocomial spreading of the virus at the same time. This is also to protect expensive and potentially easily damaged ultrasound equipment. Protection of HCPs is also a priority during the work-up phase of PUI presenting for urgent obstetric scan. The PUI with non-urgent indications should be re-directed to 'respiratory clinic' for confirmatory testings. Ultrasound providers who unknowingly examine women who are subsequently confirmed with SARS-CoV-2 infection need to be self-quarantined for $>14$ days. Appropriate use of PPE, even if the HCPs are $\geq 1 \mathrm{~m}$ away from symptomatic patients, significantly decreases risk of contracting the virus [70,71]. The level of PPE (PPE, N95 or FFP3 mask, goggle, face protective shield, surgical gown, and gloves) for PUI and confirmed COVID-19 cases is set by institutional guidelines (Table 1). Reusable PPE should be collected in a clean container for re-processing. Disposable PPE should be immediately discarded in a dedicated bin after use. All the PPE must be put on before entering the isolated examination suite, and discard (if disposable) immediately after use.

For tertiary (referral) medical institution, it is pragmatic to have one (or a few) dedicated machine(s) for PUI and confirmed COVID-19 patients. Essential obstetric ultrasounds (Table 3) should be performed bedside in COVID-19 designated area with minimal HCPs present. Always wear gloves when handling with transducers previously used in examining COVID-19 patients. The point-of-care ultrasound machine in COVID-19 obstetric ward may be fully draped with plastic cover and transducer cable sleeves to prevent contamination of the internal system. Barrier protection is crucial because HLD of components inside the system is difficult and expensive, or not possible at all. After each use, the transducer should be cleaned and LLD.

If PUI and confirmed COVID-19 pregnant women need to be examined in obstetric ultrasound unit, they should be scheduled at the end of the clinic list so that the equipment and room will undergo vigorous cleaning and disinfection afterward. A designated isolation room in obstetric ultrasound should be arranged for the scanning. Single-used, non-sterile coupling gel packets may be used for any external ultrasound examination with a PUI or confirmed COVID-19 case. Any unused portion must be discarded. If gel bottle is used, it must not be topped off, refilled, or heated. The exterior of the bottle must be wiped with LLD agents after each use. For any prenatal procedures, only single use, sterile gel packets are to be used.

So far, there has been no recommendation that HLD is mandatory for ultrasound transducers after exposure to confirmed COVID-19 cases. The process of manual HLD is tedious, and requires the use of eye protection and gloves. The transducer has to be thoroughly rinsed with water after immersion in order to remove remnants of toxic disinfectants that pose contact- or inhalant-related health hazard during subsequent examinations. Automatic HLD systems for ultrasound transducer are currently available (Table 2). Automatic HLD system consists of a sealed chamber, where ultrasound transducer is placed and immersed with ultrafine aerosol of disinfectant mechanically discharged from the system. The HLD disinfectant is neutralized after $7 \mathrm{~min}$ of exposure, and the transducer is dried and ready for immediate use [52]. The automatic HLD compact system is intended to be placed immediately next to the ultrasound machine so that the probe does not need to be disconnected from the base unit.

\section{Conclusions}

The COVID-19 pandemic is still dynamic and far from over. Obstetric ultrasound examination places HCPs and women at increased risk for cross transmission of SARS-CoV-2. This guidance is based on current, yet limited information. It aims to facilitate appropriate protection of patients and HCPs. The maintenance of infection control measures assists HCPs and health care facilities to provide optimal patient care while being prepared for COVID-19 infected obstetric patients requiring essential ultrasound services. There are variations in availability of PPE and confirmatory testing for SARS-CoV2 infection in different jurisdictions, but minimum requirements need to be set. Local protocols should be updated accordingly, and shared frequently. It would be prudent to regard every HCP, pregnant woman, and their entourage as a potential source of infection. Despite the imposed limitations related to the necessity of social distancing; provision of optimal care in safe conditions should remain the primary goal of HCPs. Precautions need to extend way beyond after the pandemic of COVID-19. As disinfection technology is 
rapidly evolving, it is essential to check with the manufacturers of the ultrasound machine and the disinfectant products, and always refer to the infection control policies and protocols of individual facility.

Acknowledgments: We thank Sommai Viboonchart, Suparat Jaingam, Chutima Yaiyiam, and Supitchaya Surasereewong for their administrative assistance.

Research funding: None declared.

Author contributions: All authors have accepted responsibility for the entire content of this manuscript and approved its submission.

Competing interests: Authors state no conflict of interest. This article does not endorse or promote any specific commercial products. It is the responsibility of each entity to follow ultrasound machine manufacturer guidelines and applicable local or institutional infection control recommendations.

\section{References}

1. Favre G, Pomar L, Qi X, Nielsen-Saines K, Musso D, Baud D. Guidelines for pregnant women with suspected SARS-CoV-2 infection. Lancet Infect Dis 2020;20:P652-653. https://doi.org/ 10.1016/s1473-3099(20)30157-2.

2. Nawapun K, Phithakwatchara N, Jaingam S, Viboonchart S, Mongkolchat N, Wataganara T. Advanced ultrasound for prenatal interventions. Ultrasonography 2018;37:200-10.

3. Skowronek P, Wojciechowski A, Leszczynski P, Olszewski P, Sibinski $M$, Polguj $M$, et al. Can diagnostic ultrasound scanners be a potential vector of opportunistic bacterial infection?. Med Ultrason 2016;18:326-31.

4. Westerway SC, Basseal JM. The ultrasound unit and infection control - are we on the right track?. Ultrasound 2017;25:53-7.

5. Westerway SC, Basseal JM, Abramowicz JS. Medical ultrasound disinfection and hygiene practices: WFUMB global survey results. Ultrasound Med Biol 2019;45:344-52.

6. Hoyer R, Adhikari S, Amini R. Ultrasound transducer disinfection in emergency medicine practice. Antimicrob Resist Infect Control 2016;5:12.

7. Abramowicz JS, Evans DH, Fowlkes JB, Marsal K, terHaar G, Committee WS. Guidelines for cleaning transvaginal ultrasound transducers between patients. Ultrasound Med Biol 2017;43: 1076-9.

8. Nyhsen CM, Humphreys H, Koerner RJ, Grenier N, Brady A, Sidhu P, et al. Infection prevention and control in ultrasound - best practice recommendations from the European society of radiology ultrasound working group. Insights Imaging 2017;8:523-35.

9. Ashokka B, Loh MH, Tan CH, Su LL, Young BE, Lye DC, et al. Care of the pregnant woman with coronavirus disease 2019 in labor and delivery: anesthesia, emergency cesarean delivery, differential diagnosis in the acutely ill parturient, care of the newborn, and protection of the healthcare personnel. Am J Obstet Gynecol 2020; 223:66-74.
10. Borowski D, Sieroszewski P, Czuba B, Jaczynska R, Anna K, Kwiatkowski S, et al. Polish society of gynecology and obstetrics statement on safety measures and performance of ultrasound examinations in obstetrics and gynecology during the SARS-CoV2 pandemic. Ginekol Pol 2020;91:231-4.

11. Dashraath P, Wong JLJ, Lim MXK, Lim LM, Li S, Biswas A, et al. Coronavirus disease 2019 (COVID-19) pandemic and pregnancy. Am J Obstet Gynecol 2020;222:521-31.

12. Poon LC, Abramowicz JS, Dall'Asta A, Sande R, Haar Gt, Maršal K, et al. ISUOG Safety Committee position statement on safe performance of obstetric and gynecological scans and equipment cleaning in context of COVID-19. Ultrasound Obstet Gynecol 2020;55:709-12. https://doi.org/10.1002/uog.22027.

13. Poon LC, Yang H, Kapur A, Melamed N, Dao B, Divakar H, et al. Global interim guidance on coronavirus disease 2019 (COVID-19) during pregnancy and puerperium from FIGO and allied partners: information for healthcare professionals. Int I Gynaecol Obstet 2020;149:273-86.

14. Bai Y, Yao L, Wei T, Tian F, Jin DY, Chen L, et al. Presumed asymptomatic carrier transmission of COVID-19. J Am Med Assoc 2020;323:1406-7.

15. Holshue ML, DeBolt C, Lindquist S, Lofy KH, Wiesman J, Bruce H, et al. First case of 2019 novel coronavirus in the United States. N Engl J Med 2020;382:929-36.

16. Coronaviridae Study Group of the International Committee on Taxonomy of $\mathrm{V}$. The species severe acute respiratory syndromerelated coronavirus: classifying $2019-\mathrm{nCoV}$ and naming it SARS-CoV-2. Nat Microbiol 2020;5:536-44.

17. Schwartz DA, Graham AL. Potential maternal and infant outcomes from (Wuhan) coronavirus 2019-nCoV infecting pregnant women: lessons from SARS, MERS, and other human coronavirus infections. Viruses 2020;12:194.

18. Anderson EL, Turnham P, Griffin JR, Clarke CC. Consideration of the aerosol transmission for COVID-19 and public health. Risk Anal 2020;40:902-7.

19. Wong SF, Chow KM, Leung TN, Ng WF, Ng TK, Shek CC, et al. Pregnancy and perinatal outcomes of women with severe acute respiratory syndrome. Am J Obstet Gynecol 2004;191:292-7.

20. Chen N, Zhou M, Dong X, Qu J, Gong F, Han Y, et al. Epidemiological and clinical characteristics of 99 cases of 2019 novel coronavirus pneumonia in Wuhan, China: a descriptive study. Lancet 2020;395:507-13.

21. Qiao J. What are the risks of COVID-19 infection in pregnant women?. Lancet 2020;395:760-2.

22. Rasmussen SA, Smulian JC, Lednicky JA, Wen TS, Jamieson DJ. Coronavirus Disease 2019 (COVID-19) and pregnancy: what obstetricians need to know. Am J Obstet Gynecol 2020;222:415-26.

23. Tan EK, Tan EL. Alterations in physiology and anatomy during pregnancy. Best Pract Res Clin Obstet Gynaecol 2013;27:791-802.

24. Berger $A$. Th1 and Th2 responses: what are they?. BMJ 2000;321: 424.

25. Kimberlin DW, Stagno S. Can SARS-CoV-2 infection be acquired in utero?: more definitive evidence is needed. J Am Med Assoc 2020; 323:1788-9.

26. Patane L, Morotti D, Giunta MR, Sigismondi C, Piccoli MG, Frigerio L, et al. Vertical transmission of COVID-19: SARS-CoV-2 RNA on the fetal side of the placenta in pregnancies with COVID-19 positive mothers and neonates at birth. Am J Obstet Gynecol MFM 2020:100145. https://doi.org/10.1016/j.ajogmf.2020.100145. 
27. Shanes ED, Mithal LB, Otero S, Azad HA, Miller ES, Goldstein JA. Placental pathology in COVID-19. Am J Clin Pathol 2020;154:2332.

28. Chen H, Guo J, Wang C, Luo F, Yu X, Zhang W, et al. Clinical characteristics and intrauterine vertical transmission potential of COVID-19 infection in nine pregnant women: a retrospective review of medical records. Lancet 2020;395:809-15.

29. Zhu H, Wang L, Fang C, Peng S, Zhang L, Chang G, et al. Clinical analysis of 10 neonates born to mothers with 2019-nCoV pneumonia. Transl Pediatr 2020;9:51-60.

30. Day M. Covid-19: identifying and isolating asymptomatic people helped eliminate virus in Italian village. BMJ 2020;368:m1165.

31. Wu Y, Liu C, Dong L, Zhang C, Chen Y, Liu J, et al. Coronavirus disease 2019 among pregnant Chinese women: case series data on the safety of vaginal birth and breastfeeding. BJOG 2020. https://doi.org/10.1111/1471-0528.16276.

32. Qiu L, Liu X, Xiao M, Xie J, Cao W, Liu Z, et al. SARS-CoV-2 is not detectable in the vaginal fluid of women with severe COVID-19 infection. Clin Infect Dis 2020. https://doi.org/10.1093/cid/ ciaa375.

33. Bordi L, Nicastri E, Scorzolini L, Di Caro A, Capobianchi MR, Castilletti C, et al. Differential diagnosis of illness in patients under investigation for the novel coronavirus (SARS-CoV-2), Italy, February 2020. Euro Surveill 2020;25:2000170.

34. Hong KH, Lee SW, Kim TS, Huh HJ, Lee J, Kim SY, et al. Guidelines for laboratory diagnosis of coronavirus disease 2019 (COVID-19) in Korea. Ann Lab Med 2020;40:351-60.

35. Jacofsky D, Jacofsky EM, Jacofsky M. Understanding antibody testing for COVID-19. J Arthroplasty 2020;35:S74-81.

36. Nanda A, Vura N, Gravenstein S. COVID-19 in older adults. Aging Clin Exp Res 2020;32:1199-202.

37. Wataganara $T$, Ruangvutilert $P$, Sunsaneevithayakul $P$, Russameecharoen K, Nawapun K, Phithakwatchara N. Threedimensional ultrasound for prenatal assessment of conjoined twins: additional advantages?. J Perinat Med 2017;45:667-91.

38. Wataganara T, Yapan P, Moungmaithong S, Sompagdee N, Phithakwatchara N, Limsiri P, et al. Additional benefits of threedimensional ultrasound for prenatal assessment of twins. J Perinat Med 2020;48:102-14.

39. Kampf G, Todt D, Pfaender S, Steinmann E. Persistence of coronaviruses on inanimate surfaces and their inactivation with biocidal agents. J Hosp Infect 2020;104:246-51.

40. Sartoretti T, Sartoretti E, Bucher C, Doert A, Binkert C, Hergan K, et al. Bacterial contamination of ultrasound probes in different radiological institutions before and after specific hygiene training: do we have a general hygienical problem?. Eur Radiol 2017;27:4181-7.

41. Mollura DJ, Palmore TN, Folio LR, Bluemke DA. Radiology preparedness in ebola virus disease: guidelines and challenges for disinfection of medical imaging equipment for the protection of staff and patients. Radiology 2015;275:538-44.

42. Hillier MD. Using effective hand hygiene practice to prevent and control infection. Nurs Stand 2020;35:45-50.

43. Grayson ML, Melvani S, Druce J, Barr IG, Ballard SA, Johnson PD, et al. Efficacy of soap and water and alcohol-based hand-rub preparations against live H1N1 influenza virus on the hands of human volunteers. Clin Infect Dis 2009;48:285-91.

44. Boyce JM. Alcohols as surface disinfectants in healthcare settings. Infect Control Hosp Epidemiol 2018;39:323-8.

45. Available from: www.thaicovids.com. [Accessed 22 June 2020].
46. Wataganara T, Bui TH, Choy KW, Leung TY. Debates on fetal fraction measurement and DNA-based noninvasive prenatal screening: time for standardisation?. BJOG 2016;123:31-5.

47. Available from: www.thaichana.com. [Accessed 22 June 2020].

48. Available from: https://www.si.mahidol.ac.th/th/news_covid19. asp. [Accessed 22 June 2020].

49. Westerway SC, Basseal JM, Brockway A, Hyett JA, Carter DA. Potential infection control risks associated with ultrasound equipment - a bacterial perspective. Ultrasound Med Biol 2017; 43:421-6.

50. Spaulding EH. Chemical versus physical cleansing. Infect Control 1983;4:8-9.

51. McDonnell G, Burke P. Disinfection: is it time to reconsider spaulding?. J Hosp Infect 2011;78:163-70.

52. Merz E. Is transducer hygiene sufficient when vaginal probes are used in the clinical routine?. Ultraschall der Med 2016;37:137-9.

53. World Federation for Ultrasound in Medicine \&, Biology, Abramowicz JS, Basseal JM. World federation for ultrasound in medicine and biology position statement: how to perform a safe ultrasound examination and clean equipment in the context of COVID-19. Ultrasound Med Biol 2020;46:1821-6.

54. Kac G, Podglajen I, Si-Mohamed A, Rodi A, Grataloup C, Meyer G. Evaluation of ultraviolet $C$ for disinfection of endocavitary ultrasound transducers persistently contaminated despite probe covers. Infect Control Hosp Epidemiol 2010;31:165-70.

55. Leroy S. Infectious risk of endovaginal and transrectal ultrasonography: systematic review and meta-analysis. J Hosp Infect 2013;83:99-106.

56. Buescher DL, Mollers M, Falkenberg MK, Amler S, Kipp F, Burdach J, et al. Disinfection of transvaginal ultrasound probes in a clinical setting: comparative performance of automated and manual reprocessing methods. Ultrasound Obstet Gynecol 2016;47: 646-51.

57. Lucet JC, Heard I, Roueli A, Lafourcade A, Mandelbrot L, Estellat C, et al. Transvaginal ultrasound probes are human papillomavirusfree following low-level disinfection: cross-sectional multicenter survey. Ultrasound Obstet Gynecol 2019;54:688-95.

58. Carey RF, Herman WA, Retta SM, Rinaldi JE, Herman BA, Athey TW. Effectiveness of latex condoms as a barrier to human immunodeficiency virus-sized particles under conditions of simulated use. Sex Transm Dis 1992;19:230-4.

59. Belouzard S, Millet JK, Licitra BN, Whittaker GR. Mechanisms of coronavirus cell entry mediated by the viral spike protein. Viruses 2012;4:1011-33.

60. Adhikari S, Blaivas M, Morrison D, Lander L. Comparison of infection rates among ultrasound-guided versus traditionally placed peripheral intravenous lines. J Ultrasound Med 2010;29: 741-7.

61. Wu M, McIntosh J, Liu J. Current prevalence rate of latex allergy: why it remains a problem?. J Occup Health 2016;58:138-44.

62. Solaimalai D, Devanga Ragupathi NK, Ranjini K, Paul H, Verghese VP, Michael JS, et al. Ultrasound gel as a source of hospital outbreaks: Indian experience and literature review. Indian J Med Microbiol 2019;37:263-7.

63. Belard S, Tamarozzi F, Bustinduy AL, Wallrauch C, Grobusch MP, Kuhn W, et al. Point-of-Care ultrasound assessment of tropical infectious diseases-a review of applications and perspectives. Am J Trop Med Hyg 2016;94:8-21.

64. Wataganara T, Seshadri S, Leung TY, Matter C, Ngerncham M, Triyasunant N, et al. Establishing prenatal surgery for 
myelomeningocele in Asia: the Singapore consensus. Fetal Diagn Ther 2017;41:161-78.

65. Deprest J, Choolani M, Chervenak F, Farmer D, Lagrou K, Lopriore $\mathrm{E}$, et al. Fetal diagnosis and therapy during the COVID-19 pandemic: guidance on behalf of the international fetal medicine and surgery society. Fetal Diagn Ther 2020:1-10. https://doi.org/ $10.1159 / 000508254$.

66. Deprest J, Van Ranst M, Lannoo L, Bredaki E, Ryan G, David A, et al. SARS-CoV2 (COVID-19) infection: is fetal surgery in times of national disasters reasonable?. Prenat Diagn 2020. https://doi. org/10.1002/pd.5702.

67. Ye G, Lin H, Chen S, Wang S, Zeng Z, Wang W, et al. Environmental contamination of SARS-CoV-2 in healthcare premises. J Infect. 2020;12:43.

68. Ren SY, Wang WB, Hao YG, Zhang HR, Wang ZC, Chen YL, et al. Stability and infectivity of coronaviruses in inanimate environments. World J Clin Cases 2020;8:1391-9.

69. Heffernan DS, Evans HL, Huston JM, Claridge JA, Blake DP, May AK, et al. Surgical infection society guidance for operative and perioperative care of adult patients infected by the severe acute respiratory syndrome coronavirus-2 (SARS-CoV-2). Surg Infect 2020;21:301-8.
70. Moore D, Gamage B, Bryce E, Copes R, Yassi A, Group BCIRPS. Protecting health care workers from SARS and other respiratory pathogens: organizational and individual factors that affect adherence to infection control guidelines. Am J Infect Control 2005;33:88-96.

71. Ong SWX, Tan YK, Chia PY, Lee TH, Ng OT, Wong MSY, et al. Air, surface environmental, and personal protective equipment contamination by severe acute respiratory syndrome coronavirus 2 (SARS-CoV-2) from a symptomatic patient. J Am Med Assoc 2020;323:1610-2.

72. Boelig RC, Manuck T, Oliver EA, Di Mascio D, Saccone G, Bellussi F, et al. Labor and delivery guidance for COVID-19. Am J Obstet Gynecol MFM 2020;2:100110.

73. Basseal JM, Westerway SC, McAuley T. COVID-19: infection prevention and control guidance for all ultrasound practitioners. Australas J Ultrasound Med 2020;23:90-5.

74. Poon LC, Yang H, Dumont S, Lee JCS, Copel JA, Danneels L, et al. ISUOG Interim Guidance on coronavirus disease 2019 (COVID-19) during pregnancy and puerperium: information for healthcare professionals - an update. Ultrasound Obstet Gynecol 2020;55: 848-62. 